\title{
EEF1B2P1 Gene
}

National Cancer Institute

\section{Source}

National Cancer Institute. EEF1B2P1 Gene. NCI Thesaurus. Code C38959.

Human EEF1B2P1 gene is located in the vicinity of $15 q 21.2$ and is approximately $1 \mathrm{~kb}$ in length. The product is a processed pseudogene, which produces an RNA transcript but does not encode a protein product, that has no apparent cellular function. 